\title{
Estimation of initial values of the HMS model parameters: application to the basin of Bin El Ouidane (Azilal, Morocco)
}

\author{
A. Ahbari ${ }^{1}$, L. Stour ${ }^{1}$, A. Agoumi ${ }^{2}$, N. Serhir ${ }^{2}$ \\ 1. Laboratory of Process and Environment Engineering, Faculty of Sciences and Techniques of Mohammedia, Hassan II \\ University of Casablanca, B.P. 146 Mohammedia 28806, Morocco. \\ 2. Laboratory of Civil Engineering, Hydraulic, Environment and Climate, Hassania School of Public Works, Casablanca, \\ Morocco.
}

Received 29 Apr 2017,

Revised 17 Jul 2017,

Accepted 21 Jul 2017

Keywords

$\checkmark$ HMS;

$\checkmark$ estimation;

$\checkmark$ parameter;

$\checkmark$ initial value;

$\checkmark$ Bin El Ouidane

AhbariAbdellatif ahbariabdellatif@hotmail.fr $\mathbf{+ 2 1 2 6 6 7 5 4 7 0 5 5}$

\section{Abstract}

The HMS(hydrologic modeling system) model is one of the most used model thanks to its capabilities and panoply of modelling formalisms. However, more effort should be done to facilitate the estimation of initial values of parameters of the HMS model. In this article, we propose a comprehensive approach to estimate initial values of the parameters of the HMS formalisms. The formalisms concerned are the five loss methods, the simple canopy method and the simple surface method. The approach use data of the African soil grid $250 \mathrm{~m}$ data for parameters estimated based on soil properties, a supervised classified ETM+ satellite image for parameters needing land use characteristics and the daily discharge for parameter demanding stream flow recession analysis. The basin of Bin El Ouidane was chosen as a case of study, in order to assimilate the estimation approach and the data utilization.

\section{Introduction}

The hydrologic model is a crucial and decisive tool in water resources management field. Indeed, one of the most used model thanks to its capabilities and panoply of modelling formalisms that offers is the HMS model. However, not all this advantages would be useful if a comprehensive work is done to facilitate the utilization of these formalisms. In fact, two aspects should be investigated to accomplish this objective: the first is to explain these formalisms physically and mathematically. The second is to introduce methods to help the user estimate initial values for the parameters of these modelling formalisms. In this optic, many researches have focused on the estimation of the initial values for the SMA loss method ([1], [2] and [3]). Tough, these works realized in developed countries, where the issue of data availability and accessibility is not an obstacle, were based on preexistent soil and land use dataset. In many African countries, the problem of data is still considered as a major obstacle to perform hydrologic modelling.

In this article, we try to propose a comprehensive approach to estimate initial values of the HMS model formalisms using free accessible soil and land use data. The formalisms include five loss methods, the simple canopy method and the simple surface method. The estimation approach proposed is based on conclusions of several researches on how to estimate values of various parameters, and other recommendations we suggest to fulfil the same objective for parameters not examined in the literature. Concerning the data to use, we propose the product African Soil Grid 250m, which contains the spatial distribution of different soil properties for the African continent. For land use purpose, we have several options, starting from pre-existent land use maps, like the GlobCover and the GLC30 datasets, to the use of satellite image to produce more accurate land use map for experienced users.

In order to assimilate the process of value estimation and data use, we have applied the suggested approach to watershed formed upstream the dam of Bin El Ouidane, located in the region of Azilal, in Morocco (Figure 1). 


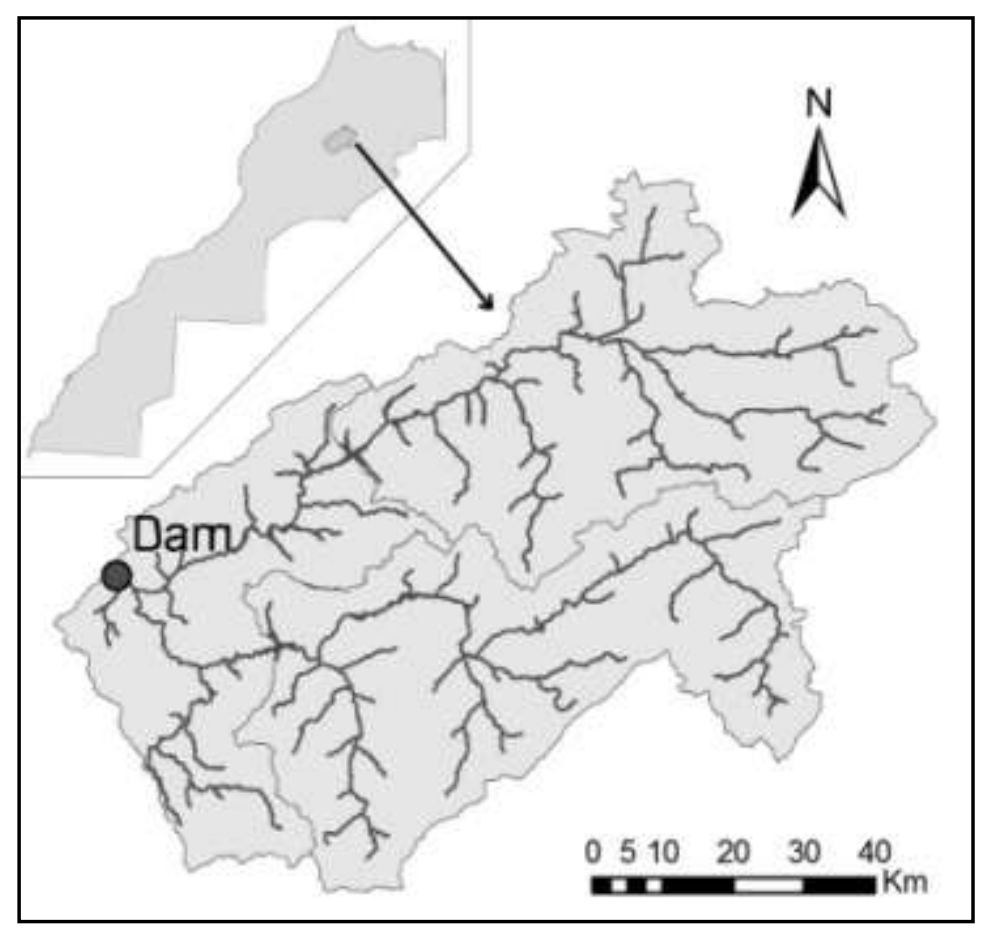

Figure 1: Situation map of the Bin El Ouidane dam watershed (Azilal-Morocco).

The basin of Bin El Ouidane is high atlas watershed of $6500 \mathrm{~km}^{2}$, a $649 \mathrm{~km}$ of perimeter and mean basin slope of $0.2806 \mathrm{~m} / \mathrm{m}$. The watershed received an average annual rainfall of $360 \mathrm{~mm}$, and drained as average annual water supplies of 853 million of $\mathrm{m}^{3}$. The basin elevation fluctuates between $730 \mathrm{~m}$ at the outlet and $3684 \mathrm{~m}$.

\section{Approach of estimation of the initial values of parameters and application to Bin El Ouidane basin}

2.1.Data required by the estimation approach

2.1.1 DEM data

The DEM of the study area is the 30m resolution ASTER GDEM V2, downloaded from the platform earth explorer.

\subsubsection{Discharge data}

For estimating some of the HMS model parameters, we will need the instant discharge at the outlet of the studied basin. In our situation, we only have the daily water supplies and the average daily discharge (calculated from the daily water supplies) at the dam of Bin El Ouidane, which is considerated as the outlet of our basin. This daily water supplies are not a measured data, but calculated using the measured output volume (released from the dam and evaporated) and the difference of water level in the reservoir. The daily water supplies data acquired were treated in order to correct these apparent errors:

- Errors in the column input of each variable (daily water supplies in the column of average daily discharge, and vice versa);

- Errors related to the decimal point input (45.12 instead of 4.512);

The quality of the discharge data should be taken into consideration in the reliability of the parameters initial values based on, and in the interpretation of the hydrologic modelling results obtained.

\subsubsection{Soil data}

In order to overcome the problem of appropriate data lack in many African countries, we suggest using the data of the African soil grid $250 \mathrm{~m}$ project. It is an update of the old $1 \mathrm{~km}$ grid map produced by the World Soil Information in collaboration with other institutes [4]. The dataset provides the spatial distribution at specific depth from the surface of various variables, such as texture of the soil, soil organic carbon content, and depth to bedrock.... This spatial distribution is resulted from a prediction process using random forest and kriging models based on in site soil profile's samples, land cover map and DEM products [4].The data are downloadable from the ISRIC website.

In our estimation approach, we will be limited to four variables: fraction of sand in the soil, fraction of silt in the soil, fraction of clay in the soil and the depth to bedrock. 


\subsubsection{Land use data}

Concerning the land use data, there is two alternatives to proceed. Either using land cover data available on free access online, for which a local validation is highly recommended before utilization for the parameters' estimation approach. Alternatively, by passing through a remote sensing supervised classification using Landsat satellite images freely accessible online at the platform earth explorer. In our situation, we have opted for a supervised classification of ETM+ satellite image. Nonetheless, if you prefer the first option, the GLC 30 data and the ESA glob Cover data are all available online.

\subsection{Maps elaborated based on the data}

\subsubsection{USDA soil map}

As we mentioned before, the African soil Grid 250m map provides the spatial distribution of various variables at specific depth from the soil. This means that the soil profile is composed of layers; each had its one spatial distribution of the subject variable. In our case, we have been limited only to the top layer $(2.5 \mathrm{~cm} \mathrm{depth})$ for three reasons:

- The hydrologic modelling, which will use the estimated initial values of the parameters, is global not distributed. Thus, such details is not very influencing;

- By previewing the spatial distribution of the soil texture for the different layers, the qualitative difference is neglected;

- The objective of the study is to converge to initial values of the model parameters, which will be optimized during the calibration phase of the modelling.

Nevertheless, if you are interested in such details, you can calculate an average value for each cell based on the values given by each layer for this cell. Then you obtain an average spatial distribution for the subject variable.

The three variables we have used to elaborate the USDA map are the fraction of sand, of silt and of clay in the soil in the first layer. The three African maps representing the three variables are downloaded from the website mentioned before, and have been subject to consecutive treatments to converge to the USDA soil map as it is resumed below:

- Treatment 1: extract the basin polygon area from the downloaded maps of sand, silt and clay;

- Treatment 2: convert the resulting three GeoTIFF maps into ASCII format;

- Treatment 3: consist on the classification of the soil type at each cell, based on the fraction of sand, silt and clay. It uses the USDA textural triangle and the fraction ranges;

- Treatment 4: its objective is to fill the no data cells (originally found in the downloaded maps) and name the unknown soil (when the three fractions sum is not equal to 100\%). The soil textural class is given in these two cases by examining the textural class in the neighbor cells;

- Treatment 5: aims to change the "text" value of each cell to "numeric" value, in order to make further format conversion possible;

- Treatment 6: convert the ASCII map resulting from classification into GeoTIFF map format;

- Treatment 7: convert the GeoTIFF map resulting from classification into Shapefile map format;

- Treatment 8: associate to each textural soil class, its attributes in terms of porosity, saturated conductivity and front suction using values proposed in the literature [5].

The figure 2 represents the resulting USDA map of Bin El Ouidane basin.

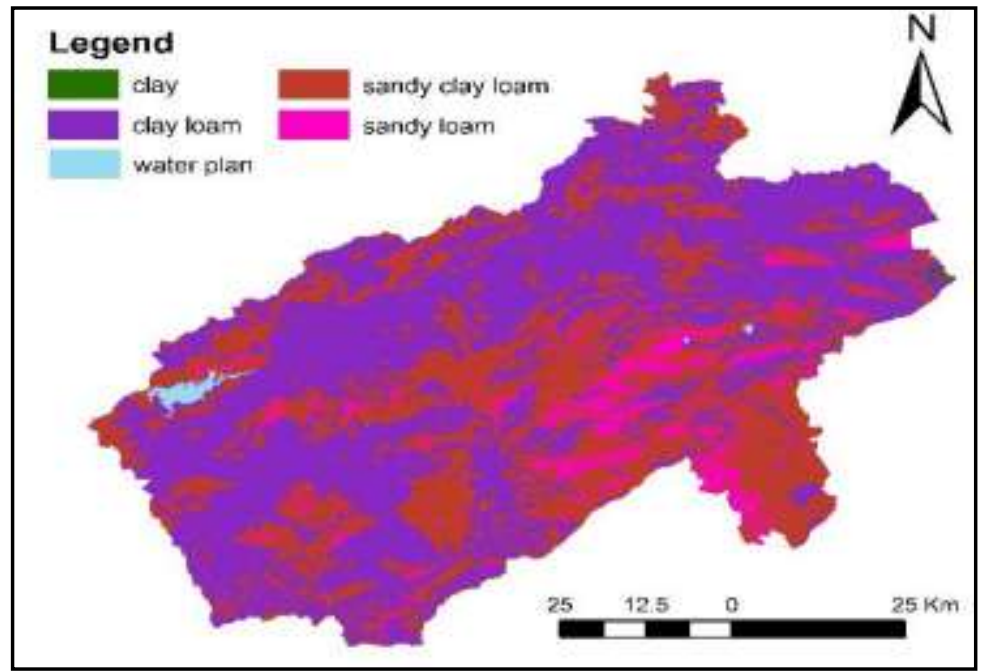

Figure 2: Elaborated USDA soil map of the basin of Bin El Ouidane. 


\subsubsection{SCS soil map}

To pass from USDA textural class to SCS soil class, we have used the correspondence proposed by [6] cited in [7]. Table 1 resumes this step.

Table 1: Correspondence between USDA and SCS soil class in the basin of Bin El Ouidane, using the table provided by [6].

\begin{tabular}{|c|c|}
\hline USDA class & Equivalent SCS class according to [6] \\
\hline Sandy loam & B \\
\hline Sandy clay loam & B \\
\hline Clay loam & C \\
\hline Clay & D \\
\hline
\end{tabular}

Therefore, the output SCS soil map is defined in the figure 3 below. Notice here that the impervious area, referring in the HMS hydrologic modelling to the percent of impervious of the basin, is represented here by the area occupied by the water plan in the basin.

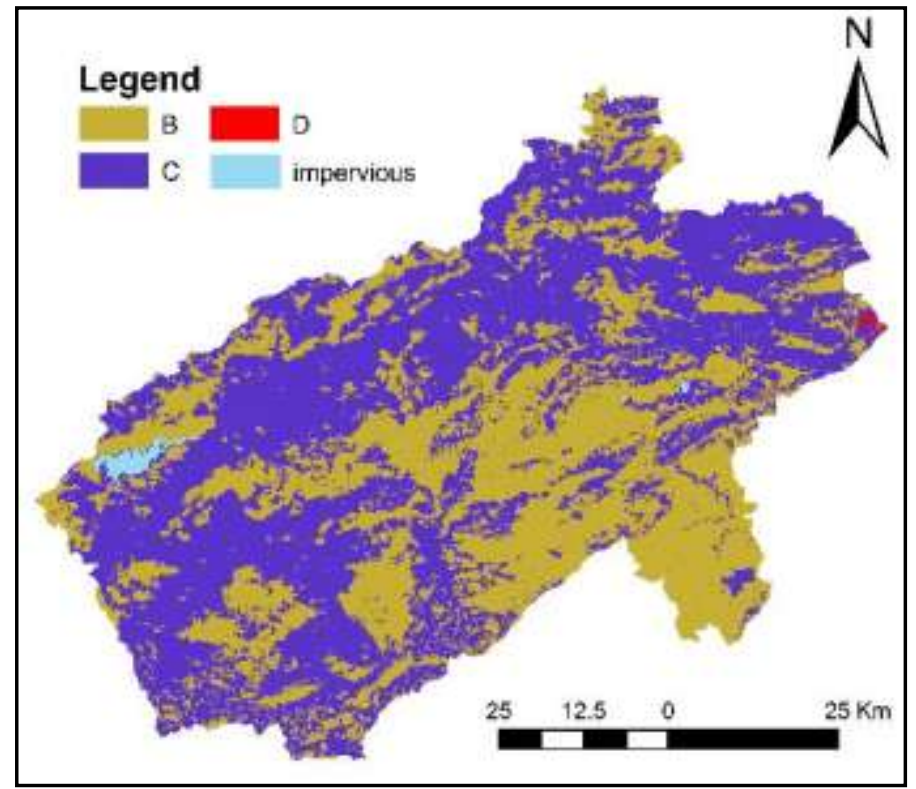

Figure 3: Elaborated SCS soil map of the basin of Bin El Ouidane.

\subsubsection{SCSland use map}

As mentioned before, we have chosen to proceed by a supervised classification of the two ETM+ satellite images representing our region of study. In addition, three other type of data were used to facilitate this supervised classification:

- A high definition satellite Bing map. Used to identify the different SCS land use classes present inside the basin perimeter. The map was downloaded using the software SASPlanet 17707;

- A forest map representing the majority of the region. Used to name the forest class identified in the satellite Bing map.

- Data of crop type and dominance provided by the provincial division of agriculture. Used to name the crop class identified in the satellite Bing map.

Figure 4 represent the SCS land use map obtained.

\subsection{Estimation approach and application}

\subsubsection{Simple canopy method}

- Initial canopy storage (\%): It is an initial condition input that represent the percent of the max canopy storage filled at the beginning of the simulation. As an initial value, we propose to start the simulation after a no rainfall period, which make a value of $0 \%$ appropriate. This assumption should be respected in the choice of the simulation periods later in the hydrologic modeling.

- Max canopy storage (mm): A formalism parameter representing the maximum depth of water that can be intercepted by vegetation. The initial value is estimated by using the SCS land use map of the basin, and the suggested values mentioned in [8] and reported in [3] (table 2). 


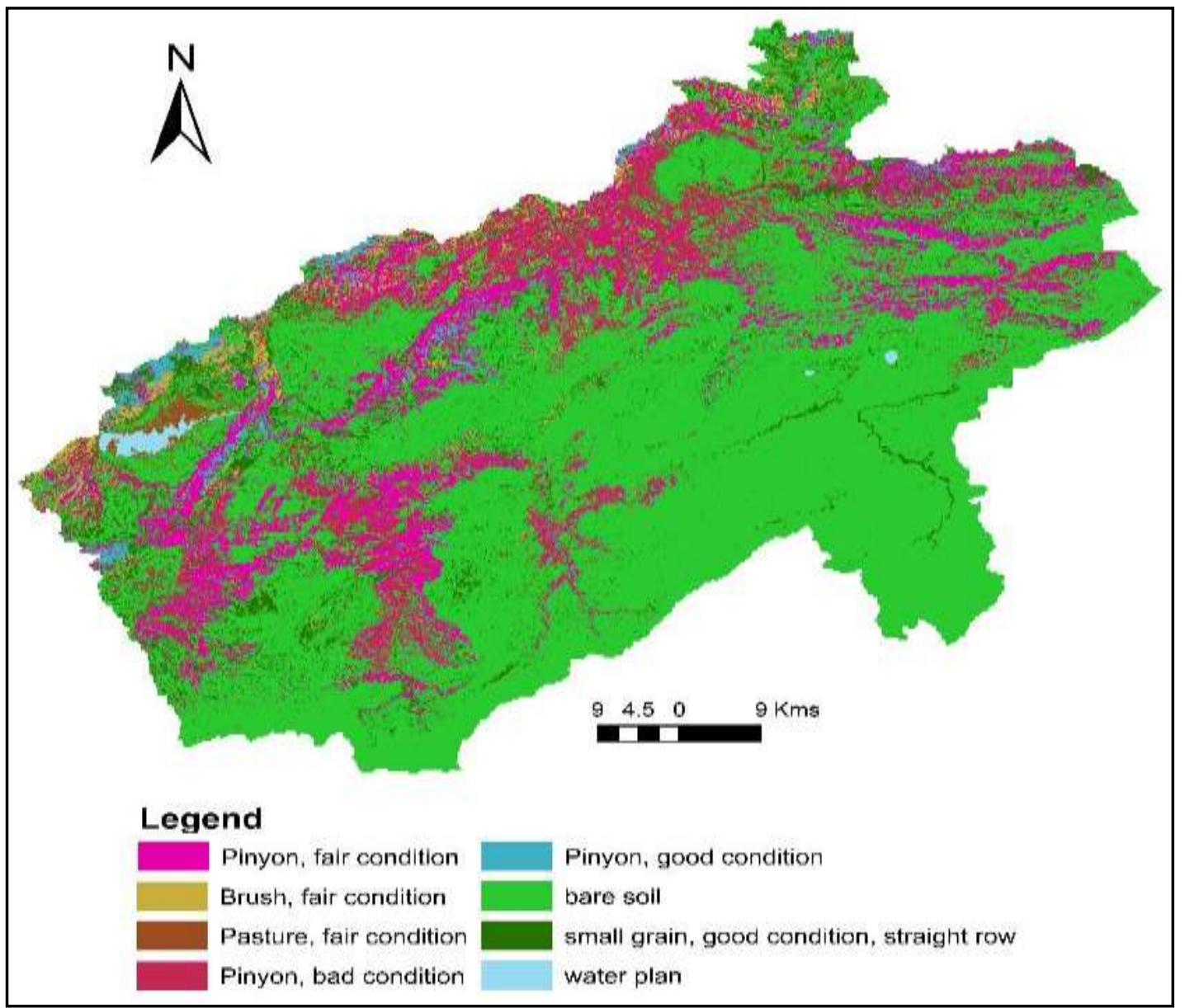

Figure 4: Elaborated SCS land use map of the basin of Bin El Ouidane.

Table 2: Values of the max canopy parameter depending on the type of vegetation, according to [8].

\begin{tabular}{|c|c|c|c|c|c|}
\hline \multicolumn{2}{|c|}{ According to [8] } & \multicolumn{4}{|c|}{ Application in the Bin El Ouidane basin } \\
\hline Type of vegetation & $\begin{array}{c}\text { Max canopy } \\
\text { storage (mm) }\end{array}$ & SCS land use class & $\begin{array}{l}\text { Area } \\
\left(\mathrm{Km}^{2}\right)\end{array}$ & $\begin{array}{l}\text { Weight } \\
\text { coefficient }\end{array}$ & $\begin{array}{c}\text { Basin } \\
\text { average value } \\
(\mathrm{mm})\end{array}$ \\
\hline $\begin{array}{l}\text { species of vegetation } \\
\text { is not directly known }\end{array}$ & 1.270 & $\begin{array}{l}\text { small grain, straight } \\
\text { row, good condition }\end{array}$ & 492.295 & 0.08 & \multirow{4}{*}{0.79} \\
\hline $\begin{array}{c}\text { grasses and } \\
\text { deciduous trees }\end{array}$ & 2.032 & $\begin{array}{c}\text { Brush, fair } \\
\text { condition+ Pasture, } \\
\text { fair condition }\end{array}$ & 207.794 & 0.04 & \\
\hline coniferous trees & 2.540 & $\begin{array}{c}\text { Pinyon, good } \\
+ \text { fair+bad condition }\end{array}$ & 1511.496 & 0.24 & \\
\hline & & Other classes & 4337.579 & 0.64 & \\
\hline
\end{tabular}

Consequently, the basin average value calculated using the estimation method and the data mentioned is 0.79 $\mathrm{mm}$.

\subsubsection{Simple canopy method}

- Initial surface storage (\%): It is an initial condition input that represent the percent of the max surface storage filled at the beginning of the simulation. As an initial value, we propose to start the simulation after a no rainfall period, which make all the water stored in the basin depression either evaporated or infiltrated. In this condition, a value of $0 \%$ is appropriate. This assumption should be respected in the selection of the simulation periods.

- Max surface storage ( $\mathrm{mm})$ : It is estimated in correlation with the slope (\%) of the catchment surface ([2] and [3]). Table 3 resumes the concept.

Therefore, we can opt for $9.77 \mathrm{~mm}$ as an average basin value for the basin of Bin El Ouidane. 
Table 3: Values of the max surface parameter depending on the basin slope (\%), and obtained value for our basin

\begin{tabular}{|c|c|c|c|c|c|}
\hline \multicolumn{3}{|c|}{ According to [2] and [3] } & \multicolumn{3}{c|}{ Application in the Bin El Ouidane basin } \\
\hline Surface description & $\begin{array}{c}\text { Slope } \\
(\%)\end{array}$ & $\begin{array}{c}\text { Max surface } \\
\text { storage (mm) }\end{array}$ & $\begin{array}{c}\text { Area } \\
\left(\mathrm{Km}^{2}\right)\end{array}$ & $\begin{array}{c}\text { Weight } \\
\text { coefficient }\end{array}$ & $\begin{array}{c}\text { Basin average } \\
\text { value (mm) }\end{array}$ \\
\hline Paved impervious area & NA & $3.2-6.4$ & - & - & \multirow{2}{*}{9.77} \\
\hline Steep, smooth slopes & $>30$ & 1 & 2406.33 & 0.36 & \\
\cline { 1 - 4 } Moderate to gentle slope & $5-30$ & $12.7-6.4$ & 3662.04 & 0.56 & \\
\hline Flat, Furrowed land & $0-5$ & 50.8 & 457.64 & 0.08 & \\
\hline
\end{tabular}

\subsubsection{SCS CN loss method parameters' estimation}

- Percent of impervious (\%): An input non calibrated parameter, that represent the percent of the basin surface which is impervious and directly connected to the stream flow. In our case, and due to the difficulty to determine precisely its value, we suggest relating it to the percent of water plan as a minimum value. Thus, the percent of impervious of the Bin El Ouidane basin is $0.4 \%$, deducted from the land use map elaborated.

The real value would be defined more accurately in the hydrologic modelling process, by searching the value that give the best efficiency.

- CN: An input parameter depending essentially on the SCS soil and SCS land use maps.

The software WMS (watershed modelling system) and the ArcGIS extension HEC-GeoHMS can calculate an average basin value by providing as input the two maps. In our case, we have used the WMS software, which calculated automatically an average basin value of 83.87 using inputted land use and soil type maps.

- Initial abstraction $I_{a}(\mathrm{~mm})$ : It represents the presence of the vegetation, which prevents permanently or temporary the precipitation from reaching the soil surface. To estimate its initial value we suggest two alternatives. The first is to let the model define an initial value by using the equation (1), conclusion of studying several experimental basins in the united states [13] :

$$
I_{a}=0.2 *\left(\frac{25400-254 * C N}{C N}\right)
$$

The second option is to use the same initial value of the parameter initial loss, which will be defined later. In our case, we have opted for the first alternative, as we have already calculated the CN parameter value. In addition, this will permit us to assess the applicability of the two equations in our context.

\subsubsection{Initial and constant loss method parameters' estimation}

- Percent of impervious (\%): same as for the SCS CN method.

- Initial loss (mm): [9] proposes an approach to estimate the initial loss based on the researches of [10], [11] and [12]. The approach relates the interception aspect of the initial loss to the type of crop and forest cover. Thus, this parameter was estimated using the SCS land use map created. Table 4 represents the results obtained.

Table 4: Values of the initial loss parameter depending on the vegetation cover [9], and obtained value for our basin.

\begin{tabular}{|c|c|c|c|c|c|}
\hline \multicolumn{2}{|c|}{ According to [9] } & \multicolumn{4}{|c|}{ Application in the Bin El Ouidane basin } \\
\hline $\begin{array}{c}\text { Type of } \\
\text { vegetation }\end{array}$ & $\begin{array}{l}\text { Initial loss } \\
\quad(\mathrm{mm})\end{array}$ & SCS land use class & $\begin{array}{l}\text { Area } \\
\left(\mathrm{Km}^{2}\right)\end{array}$ & $\begin{array}{l}\text { Weight } \\
\text { coefficient }\end{array}$ & $\begin{array}{c}\text { Basin } \\
\text { average value } \\
(\mathrm{mm})\end{array}$ \\
\hline small grains & 4.064 & $\begin{array}{l}\text { small grain, straight row, good } \\
\text { condition+Brushfrair } \\
\text { condition }\end{array}$ & 651.778 & 0.008 & \multirow{4}{*}{0.75} \\
\hline forests area & $\begin{array}{c}12.7 \\
\text { (maximum } \\
\text { value) }\end{array}$ & Pinyon, all conditions & 1511.496 & 0.23 & \\
\hline $\begin{array}{l}\text { Meadow } \\
\text { grass }\end{array}$ & 2.032 & Pasture, fair condition & 48.31 & 0.1 & \\
\hline & & Other classes & 4337.579 & 0.662 & \\
\hline
\end{tabular}


Thus, the calculated average basin value resulting from the estimation method is $0.75 \mathrm{~mm}$.

- Constant rate $(\mathrm{mm} / \mathrm{hr})$ : For the constant rate, [13] views this parameter as the ultimate infiltration capacity of the soil. In addition, [14] connect it to the SCS soil types (table 5). Therefore, this parameter was estimated using the SCS soil map elaborated. For this parameter, we can define a maximum and a minimum value, to use during calibration of the model.

Table 5: Values of the constant rate parameter depending on the SCS soil type [14], and obtained value for our basin.

\begin{tabular}{|c|c|c|c|c|c|c|}
\hline \multicolumn{3}{|c|}{ According to [14] } & \multicolumn{5}{|c|}{ Application in the Bin El Ouidane basin } \\
\cline { 1 - 3 } $\begin{array}{c}\text { SCS soil } \\
\text { group }\end{array}$ & $\begin{array}{c}\text { Range of constant } \\
\text { rate (in/hr) }\end{array}$ & $\begin{array}{c}\text { Area } \\
\left(\mathrm{Km}^{2}\right)\end{array}$ & $\begin{array}{c}\text { Weight } \\
\text { coefficient }\end{array}$ & $\begin{array}{c}\text { Basin } \\
\text { minimum } \\
\text { value (mm) }\end{array}$ & $\begin{array}{c}\text { Basin } \\
\text { average } \\
\text { value (mm) }\end{array}$ & $\begin{array}{c}\text { Basin } \\
\text { maximum } \\
\text { value (mm) }\end{array}$ \\
\hline B & $0.15-0.3$ & 2882.81 & 0.4402 & \multirow{2}{*}{2.363} & 3.901 & 5.439 \\
\hline C & $0.05-0.15$ & 3661.82 & 0.5591 & & \\
\hline D & $0-0.05$ & 4.53 & 0.0007 & & \\
\hline
\end{tabular}

This means that, the average value calculated for the basin of Bin El Ouidane, using the estimation method and the data mentioned is $3.901 \mathrm{~mm}$.

\subsubsection{Green And Ampt loss method parameters' estimation}

- Percent of impervious (\%): same as for the SCS CN method

- Initial content: This parameter varies between 0 and the saturated content value. So, its initial value can be 0 if the simulation start after a prolonged period of no rainfall, and can reach roughly the saturated content value, if the simulation start after a substantial rainfall event. As an initial value, we propose to start the simulation after a no rainfall period, which make a value of $0 \%$ appropriate. This assumption should be respected in the selection of the simulation periods.

- Saturated content: The saturated content is equal to the porosity value of the soil type [13]. By consequence, we can estimate the saturated content of the basin from the USDA soil map established, using the table given by [5] available in [13]. Table 6 indicates the results found.

Table 6: Values of the saturated content parameter depending on the USDA soil type [5], and obtained value for our basin

\begin{tabular}{|c|c|c|c|c|}
\hline \multicolumn{2}{|c|}{ According to [5] } & \multicolumn{3}{c|}{ Application in the Bin El Ouidane basin } \\
\hline USDA soil type & Porosity & Area $\left(\mathrm{Km}^{2}\right)$ & $\begin{array}{c}\text { Weight } \\
\text { coefficient }\end{array}$ & $\begin{array}{c}\text { Basin average } \\
\text { value (mm) }\end{array}$ \\
\hline clay & 0.475 & 4.53 & 0.00069 & \multirow{2}{*}{0.436} \\
\hline sandy clay loam & 0.398 & 2487.60 & 0.38118 & \\
\hline sandy loam & 0.453 & 339.17 & 0.05197 & \\
\hline clay loam & 0.464 & 3661.82 & 0.56111 & \\
\hline
\end{tabular}

As a result, the average basin value estimated for our context is $0.436 \mathrm{~mm}$.

- Suction $(\mathrm{mm})$ and conductivity $(\mathrm{mm} / \mathrm{hr})$ : The same table ([14]) provides correlation between USDA textural class from one hand and suction and the conductivity values from the other hand. Average basin values of these two parameters were calculated by applying the correlations provided in the cited table into the USDA soil map elaborated (Table 7).

Table 7: Values of the saturated content parameter depending on the USDA soil type ([14]), and obtained value for our basin.

\begin{tabular}{|c|c|c|c|c|c|c|}
\hline \multicolumn{3}{|c|}{ According to [14] } & \multicolumn{3}{c|}{ Application in the Bin El Ouidane basin } \\
\hline USDA soil type & $\begin{array}{c}\text { Suction } \\
(\mathrm{mm})\end{array}$ & $\begin{array}{c}\text { Conductivity } \\
(\mathrm{mm} / \mathrm{hr})\end{array}$ & $\begin{array}{c}\text { Area } \\
\left(\mathrm{Km}^{2}\right)\end{array}$ & $\begin{array}{c}\text { Weight } \\
\text { coefficient }\end{array}$ & $\begin{array}{c}\text { Suction : } \\
\text { Basin average } \\
\text { value (mm) }\end{array}$ & $\begin{array}{c}\text { Conductivity : } \\
\text { Basin average } \\
\text { value (mm) }\end{array}$ \\
\hline clay & 714 & 0.6 & 4.53 & 0.00069 & & \multirow{2}{*}{4.276} \\
\cline { 1 - 4 } sandy clay loam & 449 & 4.3 & 2487.60 & 0.38118 & \\
\cline { 1 - 3 } sandy loam & 222 & 25.9 & 339.17 & 0.05197 & \\
\hline clay loam & 446 & 2.3 & 3661.82 & 0.56111 & & \\
\hline
\end{tabular}


Consequently, the basin average values calculated using the estimation method and the data mentioned are respectively $433.44 \mathrm{~mm}$ and $4.276 \mathrm{~mm}$ for suction and conductivity.

\subsubsection{Deficit and constant loss method parameters' estimation}

- Percent of impervious (\%): same as for the SCS CN method.

- Initial deficit (mm): To estimate the initial deficit value, [13] proposes to begin the simulation three days after the end of a precipitation event that saturated the soil, so that the soil can drain to the water content situation known as field capacity. [15] provides a table where the field capacity is correlated to USDA texture class.

Nevertheless, we have to mention here that the use of this assumption of estimation should be respected strictly in the choice of hydrologic simulation periods. This means that the simulation period should start at least three days after the end of a precipitation event.

By means of this approach and our basin USDA soil map, we have estimated an average basin value for the initial deficit (table 8).

Table 8: Values of the initial deficit parameter depending on the USDA soil field capacity [15], and obtained value for our basin.

\begin{tabular}{|c|c|c|c|c|}
\hline \multicolumn{2}{|c|}{ According to [15] } & \multicolumn{3}{c|}{ Application in the Bin El Ouidane basin } \\
\cline { 1 - 3 } USDA soil type & $\begin{array}{c}\text { Field capacity } \\
(\%)\end{array}$ & Area $\left(\mathrm{Km}^{2}\right)$ & $\begin{array}{c}\text { Weight } \\
\text { coefficient }\end{array}$ & $\begin{array}{c}\text { Basin average } \\
\text { value (mm) }\end{array}$ \\
\hline clay & 42 & 4.53 & 0.00069 & \multirow{2}{*}{6.378} \\
\hline sandy clay loam & 27 & 2487.60 & 0.38118 & \\
\hline sandy loam & 18 & 339.17 & 0.05197 & \\
\hline clay loam & 36 & 3661.82 & 0.56111 & \\
\hline
\end{tabular}

Therefore, we can note as an average basin value $6.378 \mathrm{~mm}$, by weighting each soil type's field capacity value to its occupied surface.

- Maximum deficit ( $\mathrm{mm}$ ): About this parameter, and according to [13], the calibration often shows that this parameter maximum value is obtained by multiplying the soil depth by the porosity. The soil depth is determined using the data depth to bedrock downloaded. By employing this data, and applying it to the USDA soil map of the catchment, we can estimate this parameter average value for a given basin. In our case, the depth to bedrock data were not available yet at the time we started this research, so we have considered a common soil depth for all cells. The soil depth assumed is equal to the total depth of the six layers composing the soil in the African soil grid $250 \mathrm{~m}$ data, which is $150 \mathrm{~cm}$. Table 9 show the results for this parameter.

Table 9: Values of the maximum deficit parameter depending on the USDA soil porosity and soil depth [5], and obtained value for our basin.

\begin{tabular}{|c|c|c|c|c|c|}
\hline \multicolumn{2}{|c|}{ According to [5] } & \multicolumn{4}{|c|}{ Application in the Bin El Ouidane basin } \\
\hline USDA soil type & Porosity & \multirow{2}{*}{$\begin{array}{c}\text { Soil depth } \\
(\mathrm{mm})\end{array}$} & Area $\left(\mathrm{Km}^{2}\right)$ & $\begin{array}{c}\text { Weight } \\
\text { coefficient }\end{array}$ & $\begin{array}{c}\text { Basin } \\
\text { average } \\
\text { value (mm) }\end{array}$ \\
\hline clay & 0.475 & \multirow{2}{*}{1500} & 4.53 & 0.00069 & \\
\cline { 1 - 3 } \cline { 4 - 5 } & & 2487.60 & 0.38118 & \multirow{2}{*}{653.909} \\
\cline { 1 - 1 } \cline { 4 - 5 } sandy clay loam & 0.398 & 339.17 & 0.05197 & \\
\hline clay loam & 0.453 & 0.464 & 3661.82 & 0.56111 & \\
\hline
\end{tabular}

Thus, the basin average value calculated using the estimation method and the soil characteristics data mentioned is $653.9 .9 \mathrm{~mm}$. As for table 8 , the average value is obtained by multiplying the weight coefficient of each soil type class by the product of porosity value times the soil depth value.

- Constant rate $(\mathrm{mm} / \mathrm{hr})$ : The constant rate maximum value is the hydraulic saturated conductivity [13], so we have calculated an average value for the basin using the USDA soil map and table of [5] (table $10)$. 
Table 10: Values of the constant rate parameter depending on the USDA soil conductivity [5], and obtained value for our basin.

\begin{tabular}{|c|c|c|c|c|}
\hline \multicolumn{2}{|c|}{ According to [5] } & \multicolumn{3}{|c|}{ Application in the Bin El Ouidane basin } \\
\hline USDA soil type & $\begin{array}{c}\text { Conductivity } \\
(\mathrm{mm} / \mathrm{hr})\end{array}$ & $\begin{array}{c}\text { Area } \\
\left(\mathrm{Km}^{2}\right)\end{array}$ & $\begin{array}{c}\text { Weight } \\
\text { coefficient }\end{array}$ & $\begin{array}{c}\text { Basin average } \\
\text { value (mm) }\end{array}$ \\
\hline clay & 0.6 & 4.53 & 0.00069 & \multirow{2}{*}{4.276} \\
\hline sandy clay loam & 4.3 & 2487.60 & 0.38118 & \\
\hline sandy loam & 25.9 & 339.17 & 0.05197 & \\
\hline clay loam & 2.3 & 3661.82 & 0.56111 & \\
\hline
\end{tabular}

In other words, the average value of this parameter for the basin of Bin El Ouidane is $4.276 \mathrm{~mm}$.

\subsubsection{SMA loss method parameters' estimation}

- Percent of impervious (\%): same as for the SCS CN method.

- The initial soil content (upper part of the soil), the groundwater 1 initial content (middle part of the soil) and the groundwater 2 initial content (lowest part of the soil) (\%): These three initial parameters were set to zero \%, assuming that with a simulation starting after a prolonged no rainfall period, they would converge to $0 \%$.

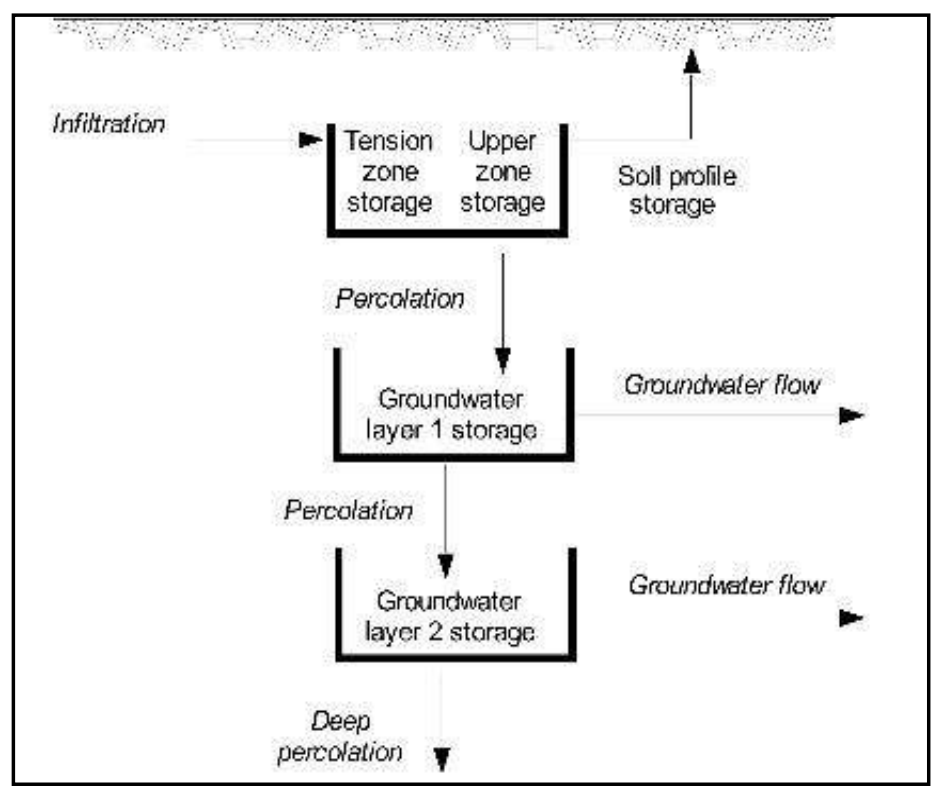

Figure 5: Scheme of the soil decomposition of the SMA loss method [13].

- Soil profile Storage $(\mathrm{mm})$ and tension zone storage $(\mathrm{mm})$ : To estimate these parameters initial values respectively, [3] suggest multiplying the depth of the soil layer by the porosity and field capacity respectively as shown in the equation (2) and (3):

$$
\begin{gathered}
\text { Soil__profile_storage }=\text { Porosity } * \text { Soil_depth (2) } \\
\text { Tension_zone_storage }=\text { Field_capacity } * \text { Soil_depth (3) }
\end{gathered}
$$

The approach was used and the two parameters were given each an initial value based on USDA soil map established and the tables that correlate soil texture class to porosity and field capacity, mentioned before. Table 11 presents the average initial values obtained for these two parameter.

This means that, the basin average values calculated using the estimation method and the data mentioned are respectively $653.909 \mathrm{~mm}$ and $471.849 \mathrm{~mm}$ for soil profile storage and tension zone storage.

- Max infiltration $(\mathrm{mm} / \mathrm{hr})$, soil percolation $(\mathrm{mm} / \mathrm{hr})$, groundwater 1 percolation $(\mathrm{mm} / \mathrm{hr})$, groundwater 2 percolation $(\mathrm{mm} / \mathrm{hr})$ : they were all assigned the same initial value, equal to the basin average hydraulic conductivity, as [3] recommended it. Table 12 indicates the resulting values. 
Table 11: Value of the soil profile storage parameter depending on the USDA soil porosity [5], and value of the tension zone storage depending on the USDA soil field capacity [15], and obtained value for our basin.

\begin{tabular}{|c|c|c|c|c|c|c|c|}
\hline \multicolumn{3}{|c|}{ According to [5] and [15] } & \multicolumn{5}{|c|}{ Application in the Bin El Ouidane basin } \\
\hline $\begin{array}{l}\text { USDA } \\
\text { soil type }\end{array}$ & Porosity & $\begin{array}{c}\text { Field } \\
\text { capacity } \\
(\%)\end{array}$ & $\begin{array}{c}\text { Soil } \\
\text { depth } \\
(\mathrm{mm})\end{array}$ & $\begin{array}{l}\text { Area } \\
\left(\mathrm{Km}^{2}\right)\end{array}$ & $\begin{array}{l}\text { Weight } \\
\text { coefficient }\end{array}$ & $\begin{array}{c}\text { Soil profile } \\
\text { storage } \\
(\mathrm{mm})\end{array}$ & $\begin{array}{l}\text { Tension zone } \\
\text { storage }(\mathrm{mm})\end{array}$ \\
\hline clay & 0.475 & 42 & \multirow{4}{*}{1500} & 4.53 & 0.00069 & \multirow{4}{*}{653.909} & \multirow{4}{*}{471.849} \\
\hline $\begin{array}{c}\text { sandy } \\
\text { clay loam }\end{array}$ & 0.398 & 27 & & 2487.60 & 0.38118 & & \\
\hline $\begin{array}{l}\text { sandy } \\
\text { loam }\end{array}$ & 0.453 & 18 & & 339.17 & 0.05197 & & \\
\hline clay loam & 0.464 & 36 & & 3661.82 & 0.56111 & & \\
\hline
\end{tabular}

Table 12: Values Max infiltration, soil percolation, groundwater 1 percolation and groundwater 2 percolation parameters depending on the USDA soil conductivity [5], and obtained value for our basin.

\begin{tabular}{|c|c|c|c|c|c|c|c|}
\hline \multicolumn{2}{|c|}{ According to [5] } & \multicolumn{6}{|c|}{ Application in the Bin El Ouidane basin } \\
\hline $\begin{array}{c}\text { USDA } \\
\text { soil type }\end{array}$ & $\begin{array}{c}\text { Conducti } \\
\text { vity } \\
(\mathrm{mm} / \mathrm{hr})\end{array}$ & $\begin{array}{c}\text { Area } \\
\left(\mathrm{Km}^{2}\right)\end{array}$ & $\begin{array}{l}\text { Weight } \\
\text { coefficient }\end{array}$ & $\begin{array}{c}\text { Max } \\
\text { infiltration } \\
(\mathrm{mm} / \mathrm{hr})\end{array}$ & $\begin{array}{c}\text { Soil } \\
\text { percolation } \\
(\mathrm{mm} / \mathrm{hr})\end{array}$ & $\begin{array}{l}\text { Groundwater } \\
1 \text { percolation } \\
(\mathrm{mm} / \mathrm{hr})\end{array}$ & $\begin{array}{c}\text { Groundwater } \\
2 \text { percolation } \\
(\mathrm{mm} / \mathrm{hr})\end{array}$ \\
\hline clay & 0.6 & 4.53 & 0.00069 & \multirow{4}{*}{4.276} & \multirow{4}{*}{4.276} & \multirow{4}{*}{4.276} & \multirow{4}{*}{4.276} \\
\hline $\begin{array}{c}\text { sandy } \\
\text { clay loam }\end{array}$ & 4.3 & $\begin{array}{c}2487.6 \\
0\end{array}$ & 0.38118 & & & & \\
\hline $\begin{array}{l}\text { sandy } \\
\text { loam }\end{array}$ & 25.9 & 339.17 & 0.05197 & & & & \\
\hline clay loam & 2.3 & $\begin{array}{c}3661.8 \\
2\end{array}$ & 0.56111 & & & & \\
\hline
\end{tabular}

As a result, we converge to a value of $4.276 \mathrm{~mm} / \mathrm{hr}$ as an average value for the four parameters: $\max$ infiltration, soil percolation, groundwater 1 percolation and groundwater 2 percolation. Although, the results which will be obtained after optimization of these four parameters should show a decreasing value from max infiltration to groundwater 2 percolation.

- Groundwater 1 storage $(\mathrm{mm})$, and coefficient (hr), groundwater 2 storage $(\mathrm{mm})$ and coefficient (hr): By means of the stream flow recession analysis developed by [11], these parameters initial values were calculated based on the daily discharge at the outlet of the basin.

The method can be resumed as follow:

- Identify all hydrograph events using the daily discharge (instant discharge is better);

- For each event do the folowing: extend the part of the decreasing discharge having the slowest slope, until the time of the event pic.

- $\quad$ Calculate $\mathrm{K}_{\mathrm{r}}$ (Constant recession) using the equation (4):

$$
K_{r}=\sqrt[t]{\frac{Q_{t}}{Q_{0}}}
$$

Where, $\mathrm{Q}_{\mathrm{t}}$ is discharge at time $\mathrm{t}$ after the pic; $\mathrm{Q}_{0}$ is the initial discharge at the beginning of the event, $\mathrm{t}$ is the time step.

- Calculate the storage coefficient using equation (5) :

$$
\text { storage_coefficient }=\frac{-1}{\operatorname{Ln}\left(K_{r}\right)}(5)
$$

- Calculate the groundwater storage $\left(\mathrm{S}_{\mathrm{t}}\right)$ using equation (6) :

$$
S_{t}=\frac{-Q_{t}}{\operatorname{Ln}\left(K_{r}\right)}
$$

The resulting storage coefficient and groundwater storage are the values of the layer 2 (figure 5). To calculate the value of the layer 1 (figure 5), we calculate the difference between the decreasing discharge and the extended line at each time t. Then, the new hydrograph resulting from the last calculation will be subject to same steps as above. Figure 6 represents the principle of calculation. 


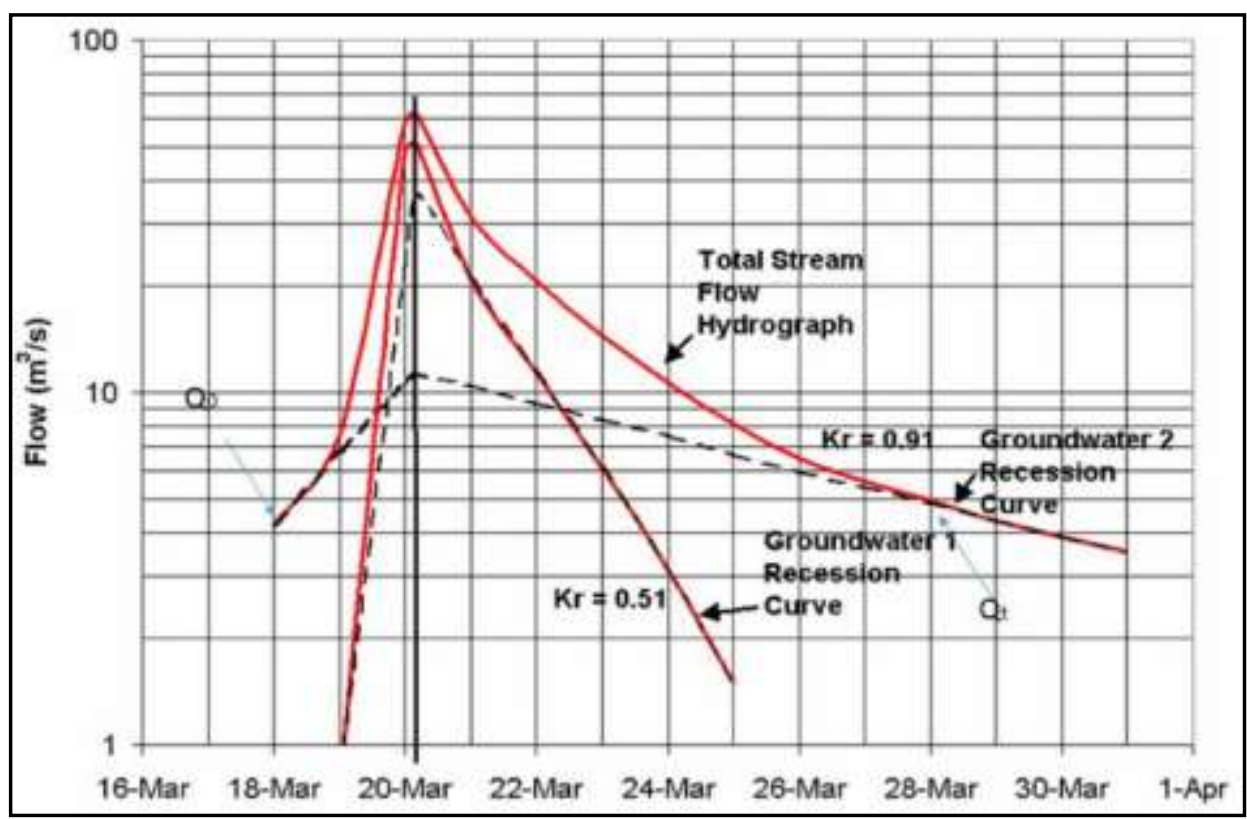

Figure 6: Principle of calculation of the groundwater 1 and 2 storage and coefficient [23].

In addition to the season of the storm event occurrence, notice that the values obtained depend on the quality and time step of the discharge records. In fact, more the time step is short; more the values of $Q_{0}$ and $Q_{t}$ are accurate, and therefore the other parameters are more precise. Figure 7 represents the graph for the hydrograph event number 7 .

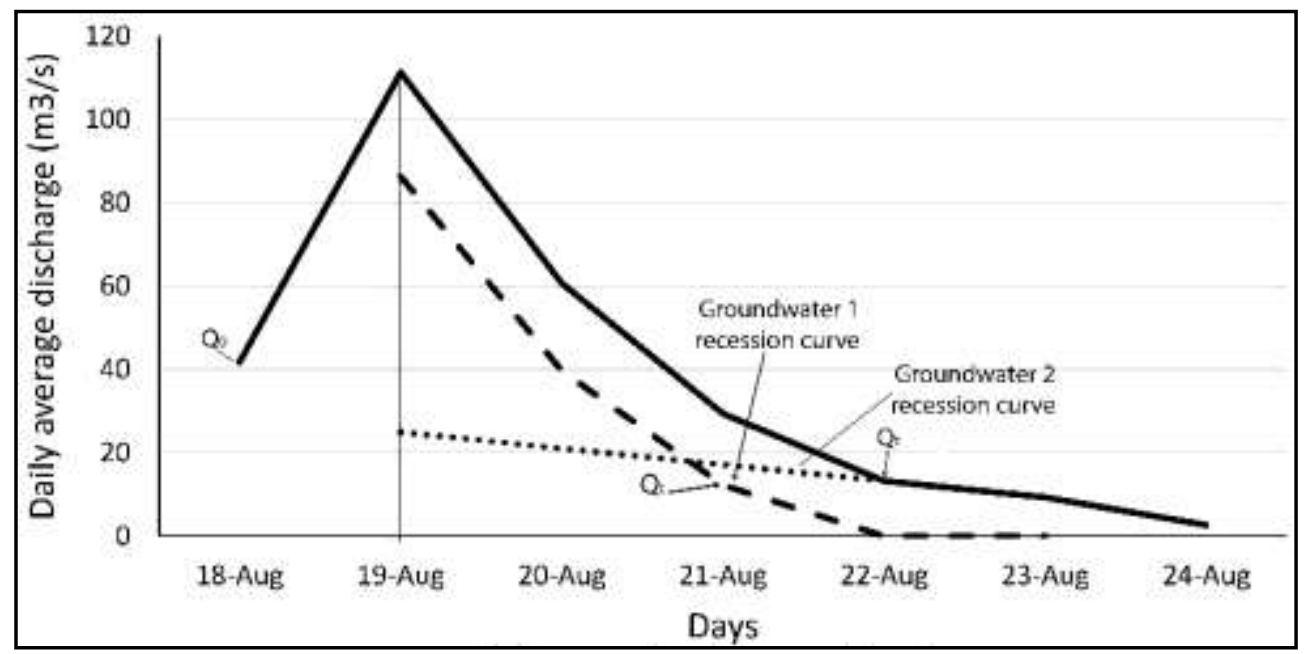

Figure 7: StormEvent 7 graph decomposition for stream flow recession's analysis.

In our case, due to the long-time step and the quality of the daily discharge, we encountered some hydrograph events with negative value of groundwater storage and coefficient for layer 1 and/or layer 2 . Figure 8 shows an example of an event for which the quality of discharge data were affecting negatively the process of analysis.

These are some recommendations we propose to select the appropriate events after calculations:

- If the values calculated for the layer 1 and 2 are negative; then eliminate the event;

- If one of the slopes of the decreasing discharge between two-time $t$ and $t+1$ is negative; then eliminate the event (figure 8). This negative slope refers to an incorrect value of the discharge;

- The slope of the decreasing discharge is continuously decreasing after each time step. This is ideal case; it proves the absence of any other storm event after the one causing the studied event. If the event shows this characteristic, it should be kept.

After eliminating those storm events, we calculated an average basin value for each of the four parameters (table 13). 


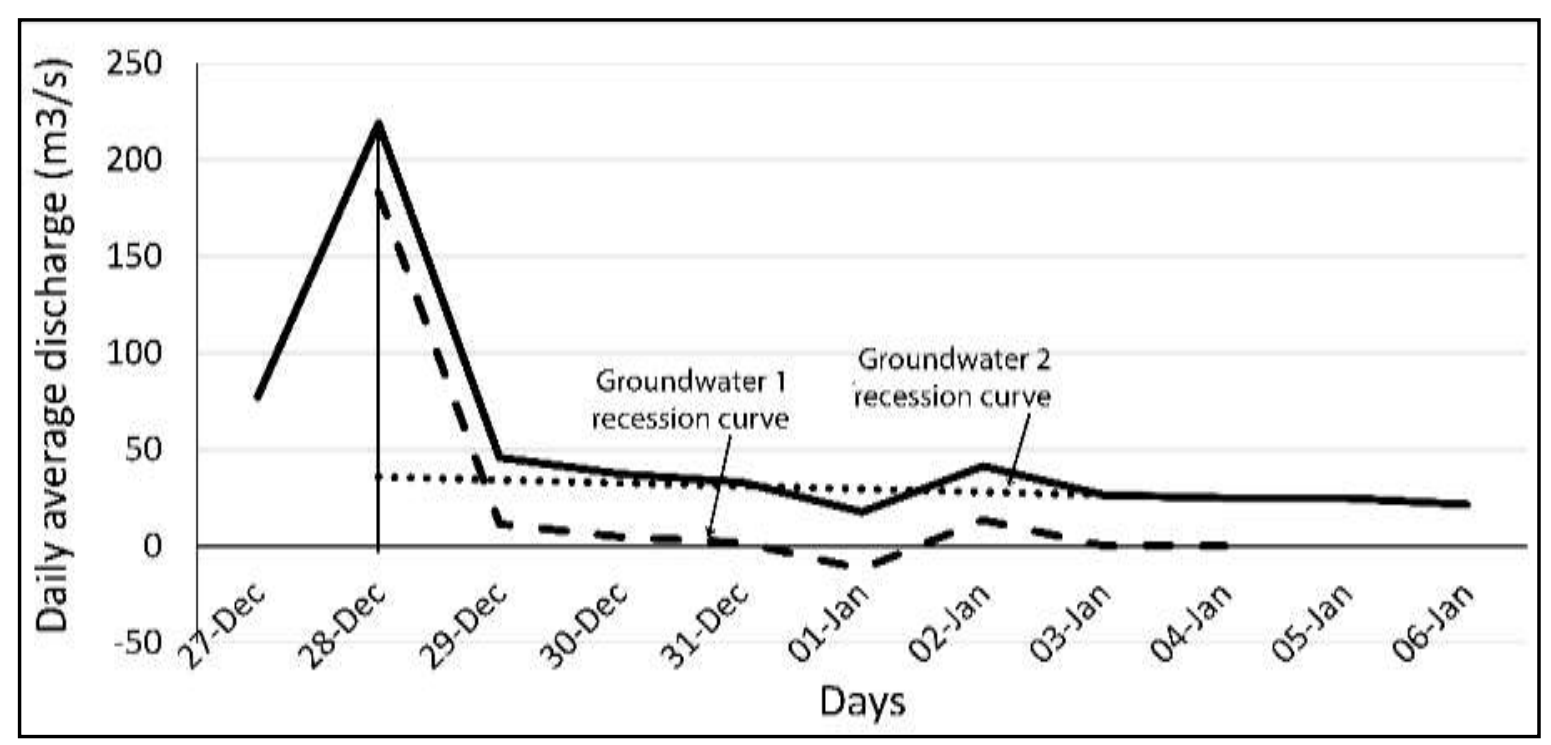

Figure 8: Example of a storm event with bad discharge data quality.

Table 13: Average basin values for the groundwater 1 storage and coefficient and groundwater 2 storage and coefficient, and ideal events used.

\begin{tabular}{|c|c|c|c|c|c|c|c|}
\hline \multirow{2}{*}{$\begin{array}{c}\text { Event } \\
\mathrm{N}^{\circ}\end{array}$} & Month & $\mathrm{Kr}$ & $\begin{array}{c}\text { maximum } \\
\text { storage St } \\
(\mathrm{mm})\end{array}$ & $\begin{array}{c}\text { storage } \\
\text { coefficient } \\
\text { (hours) }\end{array}$ & $\mathrm{Kr}$ & $\begin{array}{c}\text { maximum } \\
\text { storage St } \\
\text { (mm) }\end{array}$ & $\begin{array}{c}\text { storage } \\
\text { coefficient } \\
\text { (hours) }\end{array}$ \\
\hline 7 & August & 0.74 & 0.60 & 83.42 & 0.66 & 0.39 & 58.67 \\
\hline 9 & November & 0.95 & 8.78 & 495.31 & 0.40 & 0.007 & 26.28 \\
\hline 10 & November & 0.91 & 6.29 & 269.75 & 0.29 & 0.017 & 19.51 \\
\hline 13 & September & 0.78 & 0.20 & 99.24 & 0.47 & 0.002 & 32.23 \\
\hline 18 & May & 0.97 & 37.82 & 1046.22 & 0.66 & 0.213 & 58.23 \\
\hline 24 & March & 0.91 & 14.48 & 273.76 & 0.72 & 0.339 & 73.69 \\
\hline \multicolumn{2}{l}{ Basin average value } & - & 11.36 & 377.95 & - & 0.168 & 44.77 \\
\hline
\end{tabular}

The table shows that maximum storage and storage coefficient depends on the season on which the event occurs. In fact, when the event occurs in a rainfall season, the values of these parameters for both layer 1 and 2 are high (for example events 18 and 24). Oppositely, these values are less substantial when the storm event takes place in summer season (for example events 7 and 13).

Finally, the values obtained for the basin of Bin El Ouidane are respectively $11.36 \mathrm{~mm}$ and 377.95 hours for the groundwater 2 maximum storage and storage coefficient, and $0.168 \mathrm{~mm}$ and 44.77 hours for the groundwater 1 maximum storage and storage coefficient.

\section{Discussion and Conclusion}

The importance of a good estimation of initial values is to avoid the convergence to what we call a "false positive" optimized parameters' values. This situation is more likely probable, if the search algorithm used by the model to calibrate parameters is not looking for a global exact solution but for a local not always optimized one (Example of exact and heuristic methods). That said, if the initial values of the parameters are almost correct, then the user helps the model to avoid false positive issues.

The approach of parameters' initial values estimation presented above is essentially designated for African basins located in countries where data availability and accessibility is an issue. Nonetheless, it might be adapted to other context, if soil data are available. In fact, the absence of soil and land use data are often the major obstacle to hydrologic modelling, after, of course, the absence of hydro-climatic records. In our opinion, we judge this approach and the data employed as sufficient enough for global hydrologic modelling.

Nevertheless, in order to assess the efficiency of the estimation approach and the data used, several cases study should be tested, representing various contexts. Indeed, one of the most important thematic to examine is the sensibility of the HMS model to initial values of its parameters.

In addition, we should note that the quality of the discharge data, the uncertainties related to soil and land use data, all should be taken into consideration during the interpretation of hydrologic modelling results. 
Finally, we signal that the parameters values resulting from the estimation approach we have detailed above, are only dedicated to start simulation and should be followed by a calibration process. Otherwise, if these values are used as final optimized values, the modelling results obtained are subject to deep reconsideration and concerns.

Acknowledgments-The authors are pleased to acknowledge the hydraulic basin agency of OumEr-Rabia for providing discharge data of the dam of Bin El Ouidane, and Tom Brauer for documentation help. The authors are thankful for the anonymous reviewers for their constructive remarks.

\section{References}

1. NOAA,Technical report,Silver Spring Md., (1978) 58.

2. T.H. Bennett, J. C. Peters, Am. Soc.Civ. Eng. 10 (2000) 149. http://ascelibrary.org/doi/abs/10.1061/40517\%282000\%29149

3. M. Fleming,N.Neary, J. Hydrol. Eng. (Journal of Hydrologic Engineering), 9 (2004)175.

4. T. Hengl, G. Heuvelink, B. Kempen, J.G.B. Leenaars, M.G. Walsh, K.D. Shepherd, A. Sila, R.A. MacMillan, J. Mendes de Jesus, L.Tamene, J.E. Tondoh, PLoS ONE, 10(2015) 1371.

5. D. Hillel, Vander-éditeur, (1974) 288. Cited in Musy et al 1998.

6. A. Musy, C. Higy, Edition * $\mathrm{H}^{*} \mathrm{G}^{*} \mathrm{~A} *$ (1998) 369p. ISBN 973-98530-8-0

7. P.J. Zinke, "Forest Interception Studies in the United States," In: W.E. Sopper and H.W. Lull, Eds., International Symposium on Forest Hydrology, Pergamon Press, New York, 1967, pp. 137-161.

8. USACE, CECW-EH, (2000) 178.

9. USACE, CECW-EH, (1994) 214.

10. R.E. Horton, Pub 101, Edwards Feathers, Inc. Ann Arbor, MI.(1935) 73. In USACE (1994).

11. R.K. Linsley, M.A. Kohler, and J.L.H. Paulhus, McGraw-Hill. (1958) 340. ISBN-13: 978-0070379565.

12. W. Viessman Jr., Knapp, J.W., Lewis, G.L., Harbaugh, T.E. IEP-Dun-Donnelley, (1977) 780. ISBN-13: 978-0700224975.

13. R.W. Skaggs, R. Khaleel, Am. Soc. Agric. Eng. monograph n5(1982) 121-166.

14. W.J. Rawls, D.L. Brakensiek, and K.E. Saxton, Trans. Ame. Soc. Agr. Eng. 25 (2006) 1316-2320.

15. K.E. Saxton, W.J. Rawls, Soil Sci. Soc. Am. J. (Soil Science Society of America Journal) 70 (2006)15691578 .

16. M. Fleming, MS thesis, Tennessee Technological Univ., Cookeville, Tennessee, USA (2002) p.69.

\section{(2018); http://www.jmaterenvironsci.com}

